\title{
Decolonizing development education policy: The case of Germany
}

\author{
Daniel Bendix* - University of Kassel, Germany
}

\begin{abstract}
Germany has only recently started to discuss the possible contribution, on a conceptual basis, of post-colonial theory to development education. Drawing on key policy papers, this article explores how post-colonial and antiracist critiques of German development education have changed the field in the past decade. It first provides the history of development education in Germany and sketches the recent, decade-long debate on post-colonial perspectives in the field. The article then puts forward how development education policy deals with the topics of development, colonialism and demographics. While colonial legacies had been a topic for debate in earlier times, a decidedly post-colonial critique only entered the field about a decade ago and continues to serve as a point of tension.
\end{abstract}

Keywords: development education; post-colonial critique; Germany

\section{Introduction}

What is discussed under the label of global citizen education in the Anglo-US context is most commonly referred to in Germany as education for sustainable development, global learning or development education. Even though these approaches have different histories and, at times, use different focal points, the terms are also often used interchangeably as (near) synonyms. They are thus merged in this article under the term 'development education'. According to the key German policy document, development education aims at encouraging learners to participate in the shaping of a more just and sustainable world marked by solidarity (KMK and BMZ, 2007).

Developmenteducation takes place both in schools and in non-formal educational contexts. The actors include governmental agencies, kindergardens, primary and secondary schools, universities, adult education centres, vocational schools, faithbased organizations, non-governmental organizations (NGOs), international volunteer programmes such as weltwärts ('out into the world', by the German Federal Ministry for Economic Co-operation and Development, BMZ) and kulturweit ('culturewide', by the Federal Foreign Office) and many others. Of all the Organization for Economic Cooperation and Development (OECD) countries, Germany's spending on development education is the highest in absolute numbers (WUS-Informationsstelle Bildungsauftrag Nord-Süd, 2014).

Development education is supposed to enhance levels of knowledge to invigorate and turn people into responsible members of their society, as well as responsible global citizens. However, quite contrary to its declared objectives, development education may serve to facilitate the perpetuation of existing hierarchies and strengthen certain world views and social groups at the expense of others (Mikander, 2016; de Oliveira Andreotti and de Souza, 2012; Bryan and Bracken, 2011). 
Empirical studies in school contexts in Germany have, for instance, ascertained a direct link between the portrayal of the Global South in education material and, disturbingly, the prevalence of racism among White German students and teachers towards Black students (Marmer et al., 2010).

German academics and educators have only recently started to discuss conceptually the possible contribution of post-colonial theory to development education (Matz et al., 2017; Bechtum and Overwien, 2017; Castro Varela and Heinemann, 2016; Danielzik et al., 2013). Here, Castro Varela and Heinemann (2016: 21), for instance, call for the 'pedagogical aim of not degrading the Global South to an object that is in need of Europe's aid, but to attack ... the script of an imperialist education and to give space to "epistemologies of the South"'.

Previous analyses of education in Germany inspired by post-colonial critique have examined school books (Marmer and Ziai, 2015; Marmer et al., 2010), school partnerships (Steinwachs, 2012), educational science (Albrecht-Heide, 2005), students' world views (Kleinschmidt et al., 2015), North-South volunteering (Skoruppa, 2018; Kontzi, 2015) and educational material (Bendix et al., 2015). German development education policy has not yet come under much systematic scrutiny from a post-colonial vantage point. Studies of UK curriculum policies have ascertained the tendency in development education of reinforcing Western superiority (Andreotti, 2011).

Drawing on key policy papers from 2007, 2014 and 2015, this article focuses on shifts in, or changes to, colonial power in development education policy and interprets them in light of recent post-colonial and antiracist critique of development education in Germany. Colonial power takes effect in the present through the persistence of colonial discourses and, at the same time, impacts via disremembering (Kössler, 2015; Raghuram et al., 2009). As evident in the policy papers, the discursive sphere is read in the context of the evolution of and power relations in, German development education, as well as of sociocultural and economic global inequalities. The concrete pedagogical practice taking place in classrooms and in extracurricular contexts is beyond the scope of this article. First, I consider the history of development education in Germany and sketch the recent debate on post-colonial perspectives in development education. Then, I examine how key governmental policy documents on development education deal with the topics of development, colonialism and demography. The focus is on changes that point to more post-colonial sensitivities.

\section{The history of development education in Germany}

Development education has been conceptualized in the Federal Republic of Germany since the 1950s. Its predecessors were, on the one hand, 'colonial pedagogy', which was initiated at the beginning of the twentieth century to promote colonial policy in schools and society at large and, on the other hand, pedagogy in the spirit of the League of Nations or 'world pedagogy', aimed at 'communication in the global context' (Scheunpflug, 2012: 90; Scheunpflug and Seitz, 1995: 183-8). According to Scheunpflug (2012: 90), the context was 'collective German guilt' after the Second World War, as well as reconstruction efforts from outside leading to 'the desire to give something back in return for received aid'. Germany's 'return to the international community' of the United Nations (UN) and processes of decolonization also influenced the initiation of development education. According to Forghani (in Paschke, 2011), returning development workers actually triggered the commencement of development pedagogy in the 1950s. They believed that, in addition to changes in the Global South, political structures and the perceptions of people in the North had to change as well. 
More generally, development education in the Global North has from the outset been motivated by the 'imperative for governments, international institutions, and nongovernmental organizations (NGOs) to ensure public approval for their "development aid" programmes' (InWEnt and BMZ, 2007: 8).

Since the 1960s and in debates on international solidarity, development education in Germany has experienced further politicization and sought to provide pedagogical responses to questions of under- and over-development (Scheunpflug, 2012). Development education has further been developed since the 1990s, with the aim 'to enable responsible action of students in vein of the guiding idea of sustainable development' (Scheunpflug, 2012: 91). While the 'role of racism in development cooperation and "our" [Western] perspectives and their consequences' were already discussed in the 1990s with regard to the theory and practice of global learning, such 'suggestions did not have a wide effect' (Bechtum and Overwien, 2017: 75-6). A decidedly post-colonial critique that focuses on power-knowledge complexes and includes a focus on racism in North-South relations has remained marginal until very recently (for a notable exception, see Jouhy, 1985). One of the central differences between the 1990s and today's debate on racism and colonial continuities is the involvement of antiracist networks. Even more importantly, individual and collective agents of Color ${ }^{1}$ have taken a central role in the conceptual and practice-orientated debate. It can thus be said that, to some extent, the empire is educating back in German development education (see Ashcroft et al., 1989).

\section{Post-colonial critique in debates among educators and academics of development education}

Post-colonial theory entered development education in Germany about a decade ago. Authors and educators inspired by post-colonial critique and involved in antiracist activism began to give talks, write articles and facilitate seminars and workshops (Berliner Entwicklungspolitischer Ratschlag, 2016, 2013, 2007; Goel, 2011). I found myself in the midst of this as part of my work as educator and writer with glokal, a Berlin-based collective for post-colonial development and antiracist education and consulting. In addition to seminars and workshops, I contributed to the publication On Drummers and Helpers. Contributions to Non-Racist Development Education and Project Work (Berliner Entwicklungspolitischer Ratschlag, 2007), its updated and extended second edition, Develop-Mental Turn (Berliner Entwicklungspolitischer Ratschlag, 2013), and the booklet With Colonial Regards ... Reports and Narratives from Stays Abroad through the Lens of Antiracist Critique (glokal e.V., 2013), which has been bought or downloaded about 50,000 times, and is widely used as educational material by, for instance, volunteer-sending organizations.

While the legitimacy of post-colonial critique itself is still viewed as controversial (as discussed later in this article), some governmental institutions and NGOs or volunteer-sending organizations now officially include post-colonial perspectives in their development education practice - particularly regarding the aspect of individual self-reflection of participants with regard to internalized colonial stereotypes. Such institutions were initially reluctant, but partial change was brought about particularly by freelance facilitators, who were less prone to being incorporated by institutions and networks of critical educators - often Germans of Color and migrants (Autor*innenkollektiv, 2016; Flechtker et al., 2013). Due to the pressure from initiatives and individual educators, workshops on topics such as 'racism in language and images' and 'postcolonial critique of volunteering and tourism' were, for example, included 
in the pedagogical framework of pre- and post-departure training for international volunteers. Yet, when attempts were made to extend the criticism beyond the classroom setting of workshops to the institutional level, those active were often sidelined, silenced or even lost their jobs (Flechtker et al., 2013; Danielzik and Flechtker, 2012).

The publication of an analysis of educational materials by the organization glokal (Danielzik et al., 2013; see also Danielzik, 2013) caused lively discussions among development education stakeholders in Germany and was cited as the key contribution to post-colonial development education in the authoritative German handbook on political education (Asbrand and Scheunpflug, 2014). A controversy ensued between advocates of post-colonial critique and those who accused this perspective of imposing a particular normativity and of pursuing an authoritarian agenda. Well-established development education actors rejected the critique as ideological, totalitarian and racist - for example, because it named White people as profiteers of colonial legacies (Krämer, 2013) or because it was allegedly marked by an uncompromising, polarizing critical Whiteness perspective and 'missionary zeal' (Overwien, 2013: 41). The approach evident in glokal's publications would transform an analytical tool into a pedagogical mission (Overwien, 2013). Further responses to the documentation and accompanying articles raised the criticism that it made unjustified generalizations regarding the whole field of development education and did not acknowledge the existing works that were critical of racism and colonialism (Overwien, 2013) and that it underestimated the 'complexity of strengthening responsible subjects' (Steinbrink, 2014: 33). Furthermore, the danger of reinforcing Eurocentrism was voiced if critique centred around European colonialism (Krämer, 2013). Voices more sympathetic to post-colonial critique repudiated the counter-critique as a defence of privileges and emphasized the benefits of facing the colonial legacies in German development education policy and practice (Ziai, 2013; Open School 21, n.d.).

Even those critical of the study by glokal conceded that 'Eurocentric feelings of superiority and the degradation of other peoples and cultures ... still exist today, also in development education' (Krämer, 2013: n.p.) and that 'the examined materials in fact hardly show any approaches that can be understood as questioning current, historically evolved relations of power and domination' (Steinbrink, 2014: 33). Analysing the debate, Scheunpflug (2014) concludes that it is necessary to differentiate between the practice of development education, as evident in educational material, and its theory, that post-colonial analysis implies a problematic return of normativity and that the question of positionality needs to be addressed in a more complex manner. While the, at times, fervent dismissal of established development education educators and academics can be understood as indicative of a certain discomfort with perspectives that seem to radically challenge the status quo of development education in Germany, the initially rather stark and uncompromising stance by proponents of post-colonial and antiracist critique has also included more respect for considerable experience and past struggles in the field of development education. As with all political conflict, it was rather confrontational at the beginning, but proved to be productive for development education theory, practice, and - as will be shown in the remainder of this article for policy.

\section{The curriculum framework and 'decolonize curriculum framework!'}

The debate on colonial legacies resurfaced in the context of the reworking of the curriculum framework for development education in 2014. In 2007, a curriculum 
framework was published by BMZ and the Standing Conference of the Ministers of Education and Cultural Affairs of the Länder in the Federal Republic of Germany (KMK) for the field of global learning (KMK and BMZ, 2007). It was revised in 2014 and presented to the public in a draft version. The final version, with the title 'Curriculum Framework Education for Sustainable Development', was published in 2015. It is the central policy document and serves as a reference and guideline for development education practitioners.

According to KMK and BMZ (2015: 91), development education is supposed to give 'students orientation in an increasingly globalised world' and 'aims at developing basic competencies for shaping one's personal and professional life, for actively involving in the transformation of society and for accepting shared responsibility on a global level'. The curriculum framework makes 'suggestions for the elaboration of competencies that students should develop, thematic areas and contents that are important and suitable for developing these competencies and performance standards to be achieved' in order to attain the 'educational objectives of the learning area' (KMK and BMZ, 2015). The competencies are divided into three domains: recognition, evaluation and action. The 21 thematic areas include 'diversity of values, cultures and living conditions: diversity and inclusion', 'history of globalization: from colonialism to the "Global Village"', 'commodities from around the world: production, trade and consumption', 'global environmental change', 'demographic structures and developments', 'poverty and social security' and 'development cooperation and its institutions' (KMK and BMZ, 2015: 104).

The working group of the curriculum framework invited academics, professionals and the public to comment on a draft version. A group constituted of antiracist, post-colonial, diasporic and Black organizations and scholars (including glokal and myself), calling itself 'decolonize curriculum framework!', formulated an open letter in response. It was addressed at the working group of the curriculum framework and signed by more than 70 initiatives, organizations and associations, as well as by numerous academics (decolonize orientierungsrahmen!, 2014). The group criticized the curriculum framework quite fundamentally: in terms of the composition of its authors (primarily White, German and male); discrimination in terms of imagined target groups; adherence to hegemonic concepts and obscurity of the ideology behind the concepts used; content (not enough focus on power relations and historical as well as current epistemic and material violence); and courses for action (apolitical). Overall, 'decolonize curriculum framework!' criticized the draft version for not serving the aim of transformative education.

While some of those involved in the process of reworking the draft version of the curriculum framework dismissed the critique, others stated that it actually strengthened critical voices within the working group and circle of contributors (personal communication). The curriculum framework was subsequently reworked considerably and this process saw the inclusion of some points mentioned by 'decolonize curriculum framework!' (see below). The impact of the critique has not been acknowledged openly by those responsible for the curriculum framework, nor are any post-colonial works or works critical of racism cited or suggested as resources in the reworked version. In contrast, organizations and professionals active in the field of development education have been reprimanded by superiors - or by governmental bodies through which they are financed - for referring to or reiterating the critique (personal communication). That 'postcolonial positions [for example, those of the association glokal] were integrated' in the process of reworking the 2007 version has only very recently been mentioned by one of the contributors to the curriculum framework in an academic 
article (Bechtum and Overwien, 2017: 77). It could be said that, at present, we witness a phase in German development education in which discomfort with post-colonial critique goes along with partial acknowledgement, acceptance or incorporation of some of its perspectives - even by mainstream actors and at the highest levels of German development education governance.

\section{Tracing changes in key policy documents of German development education}

The remainder of this article analyses how this plays out in the different versions of the curriculum framework, as well as in some selected development education materials. First, I examine how the evolution of the central development education concept is conveyed in governmental policy and what changes are evident over time. Since development education has been criticized for neglecting the impact of colonialism, the article then analyses how policy documents deal with its history and its repercussions in present-day North-South relations. Finally, I scrutinize in detail one of the thematic areas of development education in the policy articles - 'demographic structures and developments'.

\section{Development qua capitalism, boxed-in post-development and the politicization of inequality}

The curriculum framework places the concept of sustainable development at the centre of its approach (KMK and BMZ, 2015). While the curriculum framework mentions 'target conflicts between the four dimensions of development' ('economic performance, social justice, ecological compatibility and good governance'), and is aware of the context of a 'variety of cultural and socio-economic situations and interests' (KMK and BMZ, 2015: 29), perspectives that question the concept of sustainable development as such are not mentioned centrally in the curriculum framework. Rather than discussing the pros and cons of capitalism with regard to development and highlighting the colonial context of the spread of capitalism, an analysis that some exceptional development education materials undertake (Informationsbüro Nicaragua, 2011), the curriculum framework's section on 'economic education' in particular, puts forward capitalist economic growth as the natural response to development problems.

However, in the rest of the curriculum framework, the link between growth and sustainable development is less rigidly drawn. For example, the possibility for decoupling is doubted - 'an effective delink of economic growth from the consumption of resources is not in sight' (KMK and BMZ, 2015: 27) - and the authors state that 'sustainable development (as key term) is not equated with growth but needs to be comprehended as sustainable development towards a quality of life for everyone, taking ecological conditions into account' (KMK and BMZ, 2015: 21). While the curriculum framework gives little inspiration in terms of 'different ways of seeing the future, in non-developmental ways' (de Sousa Santos, 2010: n.p.), post-colonial critique seems to have led to at least one noticeable change in the reworked curriculum framework. Post-development ideas were not mentioned in the draft, but the updated version now includes a box on 'Buen Vivir and sustainable development' that states:

Its present celebrity status should serve as a reminder of its absence in the dominant development discourse where it should squarely belong as the central component of the now invisible cultural pillar of sustainability. In consequence, in the central Andes, Buen Vivier [sic] is tantamount 
to sustainable development. ... As such it has mainstreamed in public consciousness the questioning of the belief that economic growth, tantamount to 'living better', necessarily leads to Buen Vivir. (KMK and $\mathrm{BMZ}, 2015:$ 31)

Here, the words of Peruvian academic Jorge Ishizawa are merely reiterated. The concept itself is not taken up again in the curriculum framework - nor is any other nonWestern development concept - and thus it appears merely to serve as an add-on to underline the willingness to take into account a variety of perspectives. It can be said to have been 'boxed in' to the curriculum framework.

While German development education policy seldom explicitly invokes the actual term 'development', its representation of the Global South and the implicit norm of the West is evident. The Global South is commonly associated with lack of economic performance, social justice, ecological sustainability, democracy and good governance and so on. A recent analysis of German social science textbooks used in secondary schools also came to the conclusion that 'the "developing world" and Africa in particular - is discursively constructed as inferior, as an anti-thesis to the "West", and as devoid of history and progress' (Marmer and Ziai, 2015: 64). Furthermore, a study of students' perspectives found that these are dominated by classical development thinking that locates the problem of 'global inequality in endogenous development deficits' (Kleinschmidt et al., 2015: 28). Diagnosing a lack of 'development' - particularly if it is portrayed as caused by endogenous factors implies the prescription of "development" in the form of modernisation, transfer of technology and capital investments (in order to stimulate economic growth)' (Ziai, 2007: 43).

In line with the focus on development policy, the concrete proposals for courses of action also seem rather limited. The section on geography in the curriculum framework, for instance, reads as follows:

Acting in the learning process can have an effect on the students' own lifestyle, for example on sustainable consumer behaviour. The geography classroom is also fertile ground for perspectives, opinions and activities centred on remote regions (partnerships with other schools, campaign participation, and aiding in development projects or [natural] disaster aid campaigns), giving students motivation for sustainable action. (KMK and $\mathrm{BMZ}, 2015$ : 229)

This is similar to the limited options that VENRO (the Confederation for Development Policy of German NGOs), the umbrella organization of development and humanitarian 'aid' NGOs in Germany, suggests is in line with development education: 'school partnerships, charity runs, and information events, world music evenings and film screenings, international chats and online discussions, school fair trade shops and climate schools as well as participation in various campaigns of development policy' (VENRO, 2010: 4). It is evident that proposals for action tend to be aligned with 'development policy' or suggest exchanges and changes in individual consumption.

It is striking that the curriculum framework does not discuss wealth and poverty as being interrelated on a global scale - a perspective that would have meant taking colonial continuities in structures of global distribution of material well-being into consideration (see Lessenich, 2016). The focus is either on poverty separately - as evident in the thematic area 'poverty and social security' - or on overconsumption and its ecological impacts. Wealth and prosperity are not discussed as an overarching 
problem. The debates in development education from the 1960s and 1970s on underand over-development seem to have been sidelined. Here, development education is no exception to the trend of depoliticizing inequalities in international development more generally since the 1980s (see Ziai, 2011). The chapter on history in the curriculum framework is a laudable exception in this regard. For the thematic area 'commodities from around the world: production, trade and consumption', it suggests the sample topics 'trans-regional trade networks from antiquity to the present day (e.g. spices, cotton, silk, coffee, sugar, cocoa)', 'slavery', 'trilateral trade and colonial goods', 'industrialisation, imperialism and colonialism', 'international division of labour and global imbalances', 'change of consumption patterns' and 'fair trade' (KMK and BMZ, 2015: 247). This compilation seems promising for reflections on the interrelatedness of the wealth of the Global North (or the global consumer class) and the poverty of the Global South.

\section{Remembering colonialism and its effects}

While an analysis of development education materials in Germany has found that these tend to refrain from linking the issue of development to colonialism (Bendix et al., 2015), this section examines how colonialism is explicitly discussed in the field of development policy at home. In the curriculum framework - even in the earlier version of 2007 - the subject of colonialism features rather prominently. One of the potential themes suggested for development education is 'the history of globalization: from colonialism to the "global village"' (KMK and BMZ, 2007: 80). In the new curriculum framework of 2015, the theme of colonialism has been substantially elaborated on, especially for the subject of history. In the thematic area 'migration and integration', a sample topic is suggested: 'changing images of the self and others in the context of transcultural processes of migration and integration (e.g. development of a feeling of European superiority in the wake of European expansion/colonisation)' (KMK and BMZ, 2015: 248). Regarding the 'implementation in school subjects and learning areas', the 'competency-oriented learning unit: European colonial policy in Africa in the 19th century' is suggested for the subject of history (KMK and BMZ, 2015: 250). Here, globalization is presented as encompassing 'a precolonial, colonial and current phase' (KMK and BMZ, 2015: 250; italics in original).

While the history of colonialism is thus quite well covered in the curriculum framework, colonial continuities are not discussed as much and, what is more important, colonialism is discussed only with regard to Africa and not other colonized regions and much less with regard to its effect on colonizing powers. Their present situation is seen to be understandable without considering colonial involvement and its legacy. This is not merely an elision, but also crucial for upholding the West's self-image as superior: 'situating colonialism outside Europe and the North Atlantic enables a division of the world into modern/developed and traditional/under-developed societies' (Gutiérrez Rodríguez, 2010: 53), rather than understanding the exploitation of the Global South as constitutive for the Global North's modernity, development and general position of global power (Rodney, 2012).

However, as a rationale for the selection of the topic of European colonial policy in Africa, we find the following statement in the new edition of the framework:

The questions and tasks developed here focus on the change of perspectives by including sources which show the colonised peoples' views. They train critical media competency and inspire to discuss the colonial heritage in the context of the present globalisation process - with 
respect to African societies and in particular to German society. They open the students' awareness of the phenomena of racism in Germany and in other societies which are structural and relevant to everyday life, and they demonstrate the ethical claim to accept social responsibility today, based on historical facts. (KMK and BMZ, 2015: 251)

This is in line with Bechtum and Overwien's (2017: 73) demand that 'dealing with knowledge production and global entanglements ... should be reflected more prominently in educational curricula and didactical materials'. The reworked curriculum framework shows signs of questioning the colonial legacy of Eurocentric knowledge production and calls for a critical reflection of 'the industrialised countries['] ... views of the universal validity of their own living conditions and values ... and have them review the existing models of development' (KMK and BMZ, 2015: 44). The curriculum framework now has a box on 'Eurocentrism' - absent in the draft version - which includes sentences such as 'are we aware that basic terms that we hardly scrutinise like wealth, poverty, growth and progress are almost totally Eurocentric?' (KMK and BMZ, 2015: 45; italics in original). Exceptional development education materials show that it is possible to tackle the issue of colonial discourse in development ideology head on, for example by analysing 'the influence of colonialism on the contemporary representation of former colonies in the media and PR' (Welthaus Bielefeld, 2014: 3), or by explicitly analysing images of development billboard advertising as well as adbust subversions of charity advertisements for their reflection of colonial discourses (see also Informationsbüro Nicaragua, 2011).

The curriculum framework thus highlights the mental and epistemological effects of the colonial legacy on the (former) colonizers. In the newly inserted box, Eurocentrism is described as a 'complex phenomenon of modern times' that legitimized 'the expansion of power and dominion' and is 'linked to the intention to convince other cultures of the validity of the [sic] own ideologies' (KMK and BMZ, 2015: 45). Yet, despite this promising attempt to reflect on the colonial legacy of liberal humanism and while considerable changes in the terms of the discussion of colonialism are discernible, it is still not conceptually mainstreamed in the curriculum framework - as is evident in the missing conceptual link between colonialism and development discussed earlier. Also, the mention of Buen Vivir and Eurocentrism and the call for reflecting European ideas of superiority in some chapters (particularly the one on history) contrast profoundly with other chapters, such as the one on economic education and with the general disregard for post-development perspectives and the colonial legacy of development thought and practice in the rest of the curriculum framework.

\section{Demographization of political issues}

As mentioned above, one of the thematic areas of the curriculum framework is 'demographic structures and developments'. To begin with, it is quite striking that'sexual and reproductive health and rights' are not invoked in the curriculum framework; that is, the curriculum framework limits itself to demographics and population developments. The outcome of the 1994 International Conference on Population and Development in Cairo had shifted the focus of population policy on to health and rights. The focus of the curriculum framework on 'demographic structures and developments' mirrors the observation of a return to more explicit population control in German development policy (Schultz and Bendix, 2015).

In the curriculum framework as a whole and in particular in the sample topic for the subject of mathematics in the 2014 draft, the thematic area of 'demographic 
structures and development' is approached for the various school subjects. In the 2014 curriculum framework draft, one of the mathematics sample topics for the thematic area is 'population growth in different world regions' (KMK and BMZ, 2015: 305) and it is sketched as a teaching example for educators. The rationale for the topic of ' $g$ lobal population development' reads as follows:

The disparate development of the global population, its rapid increase in parts of the world, but also its decline and ageing in some countries, pose a serious challenge. The provision of food, drinking water, energy and basic consumer goods is not succeeding adequately despite considerable efforts. What is more, an increase in living standards is directly or indirectly detrimental to the natural environment and therefore to the basis for life. (KMK and BMZ, 2014: 235)

While the first sentence presents population developments generally in an alarmist tone as a 'serious challenge', the combination with the second sentence reveals that the problem is seen in growing populations in the South, as only these can be connected to deficits in the provision of basic consumer goods. The third sentence highlights the critical issue of overconsumption, but it is not clear how this is connected to the perspective on decreasing and ageing populations (in the North). It is thus left open whether the problem of rising living standards and their detrimental effects on the environment is attributed to growing populations in the South or to the lifestyle in the North or to both.

While a purely mathematical approach to population without a discussion of social factors and a reflection on demographic ideologies is problematic in itself, the statistics provided in the teaching example provide further cause for concern. A table on past and future developments of the world's population provides data for 2,000 years ago and then jumps to the year 1750 (KMK and BMZ, 2014: 239). This is particularly problematic in the case of Latin America and Africa. In the former, about 90 per cent of the 80 to 100 million inhabitants were exterminated in the first five decades of colonization by European weapons, forced labour and diseases (PlumelleUribe, 2007). The latter is the only continent whose population stagnated between 1500 and 1900, due to the enslavement of millions of its inhabitants and to the societal disruptions this caused (Michailof, 2016). Desegregated data that might, for instance, show that the indigenous populations of Australia, Latin America and North America were decimated, while the European settler population grew at the same time, is not provided. Colonial genocides disappear in such statistics.

The advice for designing mathematics lessons on 'demographic structures and developments' in combination with seemingly neutral statistics allows an assessment of the ideological stance taken. Citing UN projections, this learning unit puts forward 'that even minor differences in the average number of children per woman can have a considerable influence on population development' (KMK and BMZ, 2014: 242). It goes on to state that 'provided that the number of children per woman remains constant at current levels until 2100, the global population would increase to almost 29 billion by the turn of the century' (KMK and BMZ, 2014: 242). Combined with a graph given on the same page that highlights that an increase in world population would mainly be due to population growth in Asia and Africa, it becomes evident - but tacitly, never openly and explicitly - that the 'minor difference in the average number of children per woman' refers not to an abstract world woman but to women in the Global South, and in Africa in particular. 
The perspective in the curriculum framework can be understood as framed by the ideology of demographization, a specific biopolitical epistemology that turns the size of a population or a specific population group - and not dynamic social and international relations - into the decisive variable and starting point for political strategies (Schultz, 2015). The establishment of a causal link between 'global resources' and 'growing population' and the suggestion that 'education' and 'family planning' are necessary interventions is demonstrated in the following question formulated for students in mathematics:

Which ways exist to exert influence on a rapidly growing global population with its consequences for global resources, for example? Discuss among others the impact of girls' and women's participation in education on family planning and the impact of the availability of family planning methods. (KMK and BMZ, 2014: 244)

The authors of 'decolonize curriculum framework!' (decolonize orientierungsrahmen!, 2014: n.p.) criticized the way in which the sample teaching guidelines 'put students into the position of omnipotence of pondering on ways of affecting fast growing populations in the Global South and on methods of family planning for these'. While any influence of this statement can only be assumed, the reworked curriculum framework no longer includes this example. It was not replaced with an alternative example for the subject of mathematics.

As sample topics for history, the curriculum framework puts forward 'depopulation and overpopulation in different historical contexts (e.g. Thirty Years' War, industrialisation and medical progress); changing population policy (e.g. family planning); change of the family, gender roles and age distribution (e.g. differences between industrialized, threshold and developing countries)' (KMK and BMZ, 2015: 248). The concept of the age structure of national populations evident in the third sample topic is used these days as the master frame in population policy in order to compare 'ageing' ('industrialized'), 'transitional' ('threshold') and 'high-fertility' ('developing countries') nations. Different economic potentials are then deduced from such categorization. This perspective tends to abstract not only from intra-national diversity, but also from social, economic or other power relations within and across different age groups and does not take into account how global capitalist relations define access to income and resources around the world.

For history, the discussion of population recurs in the thematic area 'global environmental changes', which, among other things, proposes the sample topic 'conditions and consequences of global population growth in the past and present' (KMK and BMZ, 2015: 248). While not explicitly causally linked, the juxtaposition of the two sample topics associates environmental changes with population growth - and not, for instance, with capitalism or colonial exploitation.

In geography, the suggestion is to deal with 'Population policies in developing and industrialised countries' via the statements "You shouldn't have any more children" - "You have to have more children"' (KMK and BMZ, 2015: 233). More information on how to go about it, and whether and how to depart from a theoretical perspective that acknowledges the class and race dimension of global as well as local pro- and anti-natalist policies, is not provided. The description of the sample topic may lead to a critical discussion, if the statements are discussed as related to power relations, inequality and utilitarian ideology, but may also reinforce colonial representations of an overpopulated South if they are not discussed in this way. The decision of which of the ways to take is left to the individual teachers. 
From the 2015 curriculum framework, it cannot be deduced how issues of population will eventually be discussed in the classroom - especially given that the sample topic for mathematics has been removed. However, it evidently does not invite facilitators to critically reflect on the problem of demographizing social, political and economic issues of power and inequality.

\section{Conclusion}

The historical introduction illustrates that while colonial legacies have previously been a topic in development education, a decidedly post-colonial critique entered the field only about ten years ago and continues to serve as a point of tension. Yet it is noteworthy that significant and promising changes in development education policy and material are taking place. The absence of substantial migration from former German colonies to Germany may have contributed to the fact that discussions of the impact of colonialism in the present continue to be marginalized. That the empire is speaking back (see Ashcroft et al., 1989) in the field of development education and that educators and activists demand post-colonial justice in terms of content and equality of representation in institutions, is a fairly recent phenomenon.

Taking into account that it is difficult to make sweeping statements about the vast field of development education in Germany, this article has highlighted that German development education policy embraces concurrent and contradictory tendencies: on the one hand, ideas of Western supremacy are perpetuated and, on the other, it seems to hesitantly acknowledge fundamental post-colonial critiques that question the dominant concept of development and call for an actual recognition of diversity in the context of a continuous colonial present.

The absence of a strong conceptual link between colonialism, modernity and development (as process, practice and vision) within the German curriculum frameworks for development education lead to colonialism being disregarded as a crucial structuring moment that continues to shape North-South relations. If colonialism is brought back into the equation, the concept of development would be unveiled as historically interwoven with racism and colonial exploitation and its contemporary effect as supportive of a racist classificatory system becomes evident (see Kothari, 2006; Wilson, 2012). Or, as Castro Varela and Heinemann (2016: 21) put it, 'it is ... politically wise and pedagogically essential to question the historical amnesia, so that the assumption of the colonial civilising mission - that an intervention into postcolonial countries is an ethical act - is not reinforced again and again.'

Notwithstanding the recent hesitant inclusion of post-development ideas and post-colonial critique, not enough room is provided for students to question dominant concepts of 'development' or to get to know alternative epistemologies. The narrative of development as an accomplishment of the West that is disconnected from exploitation and still needs to happen in the Global South means that development policy abroad is proposed as the obvious solution. Rather than destabilizing the 'superiority complex' of White people and elites in the Global North and South (see Fanon, 2008), the courses for action dominating German development education consolidate this structure. The propagation of a certain idea of development implies that assistance and aid, rather than exploitation and oppression (or solidarity), are constructed as central to the relationship between Global North and South.

A truly post- or decolonial agenda in development education depends on the transformation of the whole field and demands changes of institutional and political frameworks. Change would need a broad questioning of power structures 
in development education: at the pedagogical level (e.g. materials and didactics), in structures of governmental and non-governmental institutions (e.g. recruitment) and on the ideological level of organizations. In addition, more exchange and networking between organizations, facilitators, consultants and funders that are devoted to decolonizing development education is necessary. Interventions by networks of People of Color and antiracist initiatives have played a crucial role to date. These need to be seriously acknowledged by institutionalized actors and be given more space to influence educational agendas and structures.

\section{Note}

1 'Person/People of Color' has been introduced as a self-description by people who are racialized as not belonging to White German society (Dean, 2011). The idea is to reject imposed racist terminology and to allow for alliances among different racialized communities. In Germany, it is used in the English form as it was adapted from the US context.

\section{Notes on the contributor}

Daniel Bendix is a post-doctoral researcher and lecturer in development and postcolonial studies at the University of Kassel, Germany, and holds a PhD in development policy and management from the University of Manchester, UK. He is active with kassel postkolonial as well as with glokal, a Berlin-based association for political education. Daniel is the author of Global Development and Colonial Power: German development policy at home and abroad (Rowman \& Littlefield International, 2018).

\section{References}

Albrecht-Heide, A. (2005) 'Weißsein und Erziehungswissenschaft'. In Eggers, M.M., Kilomba, G., Piesche, P. and Arndt, S. (eds) Mythen, Masken und Subjekte: Kritische Weißseinsforschung in Deutschland. Münster: Unrast, 444-59.

Andreotti, V. (2011) Actionable Postcolonial Theory in Education. New York: Palgrave Macmillan.

Asbrand, B. and Scheunpflug, A. (2014) 'Globales Lernen'. In Sander, W. (ed.) Handbuch politische Bildung. 4th ed. Schwalbach am Taunus: Wochenschau Verlag, 401-12.

Ashcroft, B., Griffiths, G. and Tiffin, H. (1989) The Empire Writes Back: Theory and practice in postcolonial literatures. London: Routledge.

Autor*innenkollektiv (2016) 'Rassismuskritik unter prekären Bedingungen - Ehrenamtliche Erfahrungen mit rassismuskritischer Organisationsentwicklung'. In Berliner

Entwicklungspolitischer Ratschlag (ed.), Bon Voyage! Rassismuskritische Wege in der entwicklungspolitischen Bildungs- und Projektarbeit. Berlin: Berliner Entwicklungspolitischer Ratschlag, 52-6.

Bechtum, A. and Overwien, B. (2017) 'Kann postkoloniale Kritik Schule machen? Über ihre Grenzen und Potenziale für (entwicklungs-)politische Bildungsarbeit'. In Burchardt, H.-J., Peters, S. and Weinmann, N. (eds) Entwicklungstheorie von heute - Entwicklungspolitik von morgen. BadenBaden: Nomos, 59-84.

Bendix, D., Danielzik, C.-M. and Kiesel, T. (2015) 'Education for sustainable inequality? A postcolonial analysis of materials for development education in Germany'. Critical Literacy: Theories and Practices, 9 (2), 47-63.

Berliner Entwicklungspolitischer Ratschlag (2007) Von Trommlern und Helfern: Beiträge zu einer nicht-rassistischen entwicklungspolitischen Bildungs- und Projektarbeit. Berlin: Berliner Entwicklungspolitischer Ratschlag.

Berliner Entwicklungspolitischer Ratschlag (2013) Develop-mental Turn: Neue Beiträge zu einer rassismuskritischen entwicklungspolitischen Bildungs- und Projektarbeit. Berlin: Berliner Entwicklungspolitischer Ratschlag.

Berliner Entwicklungspolitischer Ratschlag (2016) Bon Voyage! Rassismuskritische Wege in der entwicklungspolitischen Bildungs- und Projektarbeit. Berlin: Berliner Entwicklungspolitischer Ratschlag. 
Bryan, A. and Bracken, M. (2011) Learning to Read the World? Teaching and learning about global citizenship and international development in post-primary schools. Dublin: Irish Aid. Online. www.ubuntu.ie/media/bryan-learning-to-read-the-world.pdf (accessed 12 January 2018).

Castro Varela, M. do Mar and Heinemann, A.M.B. (2016) 'Globale Bildungsbewegungen Wissensproduktionen verändern'. ZEP - Zeitschrift für internationale Bildungsforschung und Entwicklungspädagogik, 39 (2), 17-22.

Danielzik, C.-M. (2013) 'Überlegenheitsdenken fällt nicht vom Himmel: Postkoloniale Perspektiven auf Globales Lernen und Bildung für nachhaltige Entwicklung'. ZEP - Zeitschrift für internationale Bildungsforschung und Entwicklungspädagogik, 36 (1), 26-33.

Danielzik, C.-M. and Flechtker, B. (2012) 'Wer mit Zweitens anfängt: Bildung für nachhaltige Entwicklung kann Machtwissen tradieren'. iz3w, 329, D8-D10.

Danielzik, C.-M., Kiesel, T. and Bendix, D. (2013) Bildung für nachhaltige Ungleichheit? Eine postkoloniale Analyse von Materialien der entwicklungspolitischen Bildungsarbeit in Deutschland. Berlin: glokal.

Dean, J. (2011) 'Person/people of colo(u)r'. In Arndt, S. and Ofuatey-Alazard, N. (eds) Wie Rassismus aus Wörtern spricht: (K)Erben des Kolonialismus im Wissensarchiv deutsche Sprache: Ein kritisches Nachschlagewerk. Münster: Unrast, 597-607.

decolonize orientierungsrahmen! (2014) decolonize orientierungsrahmen! Online. https://decolonizeorientierungsrahmen.wordpress.com (accessed 8 April 2017).

de Oliveira Andreotti, V. and de Souza, L.M.T.M. (2012) Postcolonial Perspectives on Global Citizenship Education. New York: Routledge.

de Sousa Santos, B. (2010) " The world is changing in a more progressive way, and it's taking place here" - Boaventura de Sousa Santos on Bolivia Climate Summit'. Democracy Now!, 21 April. Online. www.democracynow.org/2010/4/21/the_world_is_changing_in_a (accessed 6 February 2018).

Fanon, F. (2008) Black Skin, White Masks. Trans. Markmann, C.L. London: Pluto Press.

Flechtker, B., Stein, A. and Goel, U. (2013) 'Eine unmögliche Verbindung? Rassismuskritische Bildung und entwicklungspolitische Institutionen'. In Berliner Entwicklungspolitischer Ratschlag Develop-mental Turn: Neue Beiträge zu einer rassismuskritschen entwicklungspolitischen Bildungs- und Projektarbeit. Berlin: Berliner Entwicklungspolitischer Ratschlag, 68-72.

glokal e.V. (2013) Mit kolonialen Grüßen ... Berichte und Erzählungen von Auslandsaufenthalten rassismuskritisch betrachtet. Berlin: glokal.

Goel, U. (2011) 'Rassismus- und privilegienkritische Bildungsarbeit'. In Grundmann, D. and Overwien, B. (eds) weltwärts pädagogisch begleiten. Kassel: Kassel University Press, 24-31.

Gutiérrez Rodríguez, E. (2010) Migration, Domestic Work and Affect: A decolonial approach on value and the feminization of labor. New York: Routledge.

Informationsbüro Nicaragua (2011) Fokuscafé Lateinamerika - Von der Kolonialzeit zur Unabhängigkeit in die Gegenwart - Werkheft zum Modul Geschichte und Klischees. Wuppertal: Informationsbüro Lateinamerika.

InWEnt and BMZ (2007) Förderprogramme Entwicklungspolitische Bildungsarbeit BMZ/ InWEnt. Online. www.ewik.de/coremedia/generator/ewik/de/Externe_20Links/ Referenten_2C_20Finanzierung/F_C3_B6rderprogramme_20ep_20Bildung.pdf (accessed 14 August 2017).

Jouhy, E. (1985) Bleiche Herrschaft - Dunkle Kulturen: Essais zur Bildung in Nord und Süd. Frankfurt am Main: Verlag für Interkulturelle Kommunikation.

Kleinschmidt, M., Fischer, S., Fischer, F. and Lange, D. (2015) 'Globalisierung, globale Ungleichheit und Entwicklung in den Vorstellungen von Schüler/inne/n: Die empirische Untersuchung von Lernvoraussetzungen als Ausgangspunkt für die Gestaltung Globalen Lernens'. ZEP - Zeitschrift für internationale Bildungsforschung und Entwicklungspädagogik, 38 (3), 26-30.

KMK and BMZ (2007) Orientierungsrahmen für den Lernbereich Globale Entwicklung im Rahmen einer Bildung für nachhaltige Entwicklung. Bonn, Berlin: BMZ - KMK. Online. www.ewik. de/coremedia/generator/ewik/de/Downloads/Dokumente/Orientierungsrahmen_20f_C3_ BCr_20Globales_20Lernen.pdf (accessed 14 August 2017).

KMK and BMZ (2014) Orientierungsrahmen für den Lernbereich Globale Entwicklung im Rahmen einer Bildung für nachhaltige Entwicklung (Arbeitsdokument - Zur Anhörung und Kommentierung freigegeben). Berlin: H. Heenemann.

KMK and BMZ (2015) Curriculum Framework Education for Sustainable Development (2nd updated and extended edition). Bonn-Berlin: KMK-BMZ.

Kontzi, K. (2015) Postkoloniale Perspektiven auf "weltwärts": Ein Freiwilligendienst in weltbürgerlicher Absicht. Baden-Baden: Nomos.

Kössler, R. (2015) Namibia and Germany: Negotiating the past. Münster: Westfälisches Dampfboot. 
Kothari, U. (2006) 'Critiquing "race" and racism in development discourse and practice'. Progress in Development Studies, 6 (1), 1-7.

Krämer, G. (2013) 'Augen zu vor der Schuld der Anderen: Für radikale Antirassisten sind die Bösen immer weiß'. Welt-Sichten, 9. Online. www.welt-sichten.org/artikel/17560/ (accessed 13 March 2017).

Lessenich, S. (2016) Neben uns die Sintflut: Die Externalisierungsgesellschaft und ihr Preis. München: Hanser.

Marmer, E., Marmer, D., Hitomi, L. and Sow, P. (2010) 'Racism and the image of Africa in German schools and textbooks'. International Journal of Diversity in Organisations, Communities and Nations, 10 (5), 1-12.

Marmer, E. and Ziai, A. (2015) 'Racism in the teaching of "development" in German secondary school textbooks'. Critical Literacy: Theories and Practices, 9 (2), 64-84.

Matz, E., Knake, S. and Garbe S. (2017) '“Gibt's das auch in postkolonial?": Globales Lernen vor dem Hintergrund postkolonialer Kritik'. In Emde, O., Jakubczyk, U., Kappes, B. and Overwien, B. (eds) Mit Bildung die Welt verändern? Globales Lernen für eine nachhaltige Entwicklung. Opladen: Barbara Budrich, 91-109.

Michailof, S. (2016) 'Vorprogrammierte Explosion? Welche Folgen das rasante Bevölkerungswachstum in Afrika südlich der Sahara haben könnte'. Auslandsinformationen, 32 (4), 43-56.

Mikander, P. (2016) 'Globalization as continuing colonialism: Critical global citizenship education in an unequal world'. Journal of Social Science Education, 15 (2), 70-9.

Open School 21 (n.d.) Decolonize Globales Lernen! Warum wir als Open School 21 den Offenen Brief "Decolonize Orientierungsrahmen" unterstützen. Hamburg: Open School 21. Online. www.ven-nds.de/images/ven/projekte/globales_lernen/Decolonize_Globales_Lernen-_open_ school21.pdf (accessed 6 February 2018).

Overwien, B. (2013) 'Critical Whiteness I: Falsche Polarisierung - Die Critical Whiteness-Kritik am Globalen Lernen wird ihrem Gegenstand nicht gerecht'. iz3w, 338, 38-41.

Paschke, S. (2011) 'Globales Lernen in Theorie und Praxis: Ein pädagogisches Konzept in Begründungsnot'. Unpublished MSc thesis, Universität Wien. Online. http://othes.univie.ac. at/13574/1/2011-02-02_0447657.pdf (accessed 22 August 2018).

Plumelle-Uribe, R.A. (2007) 'Von der kolonialen Barbarei zur Vernichtungspolitik des Nationalsozialismus'. African Reflections eJournal, October, 4-11. Online. www. africavenir.org/ fileadmin/downloads/e_dossiers/AFA_ejournal_0107.pdf (accessed 22 August 2018).

Raghuram, P., Madge, C. and Noxolo, P. (2009) 'Rethinking responsibility and care for a postcolonial world'. Geoforum, 40 (1), 5-13.

Rodney, W. (2012) How Europe Underdeveloped Africa. Cape Town: Pambazuka Press.

Scheunpflug, A. (2012) 'Globales Lernen - Geschichte'. In Lang-Wojtasik, G. and Klemm, U. (eds) Handlexikon Globales Lernen. Münster: Klemm und Oelschläger, 89-93.

Scheunpflug, A. (2014) 'Globales Lernen und die Debatte um Postkolonialität'. ZEP - Zeitschrift für internationale Bildungsforschung und Entwicklungspädagogik, 37 (4), 31-2.

Scheunpflug, A. and Seitz, K. (1995) Die Geschichte der entwicklungspolitischen Bildung: Zur pädagogischen Konstruktion der "Dritten Welt": Band 1: Entwicklungspolitische Unterrichtsmaterialien. Frankfurt am Main: IKO-Verlag für Interkulturelle Kommunikation.

Schultz, S. (2015) 'Reproducing the nation: The new German population policy and the concept of demographization'. Distinktion: Scandinavian Journal of Social Theory, 16 (3), 337-61.

Schultz, S. and Bendix, D. (2015) 'A revival of explicit population policy in development cooperation: The German Government, Bayer, and the Gates Foundation'. DifferenTakes, 89, 1-6. Online. https://dspace.hampshire.edu/bitstream/10009/851/1/popdev_differentakes_89.pdf (accessed 21 August 2018).

Skoruppa, D. (2018) Freiwilligendienst auf Augenhöhe? Eine machtkritische Analyse von weltwärts Süd-Nord. Köln: Kölner Wissenschaftsverlag.

Steinbrink, C. (2014) 'Die Komplexität der Stärkung mündiger Subjekte'. ZEP - Zeitschrift für internationale Bildungsforschung und Entwicklungspädagogik, 37 (4), 33.

Steinwachs, L. (2012) Zitat: "Arm, aber glücklich": Persönliche Begegnungen in Schulpartnerschaften. Berlin: Berlin Postkolonial. Online. http://berlin-postkolonial.de/cms/ images/dokumente/partnerschaftentwickleln/steinwachs_2012_zitat_arm_aber_gluecklich_ schuelerbegegnungen.pdf (accessed 14 November 2017).

VENRO (Verband Entwicklungspolitik deutscher Nichtregierungsorganisationen) (2010) Globales Lernen trifft neue Lernkultur (VENRO-Arbeitspapier 19). Bonn: Verband Entwicklungspolitik deutscher Nichtregierungsorganisationen. 
Welthaus Bielefeld (2014) Koloniale Kontinuitäten II: Unterrichtsmaterial für das Fach Geschichte (Klasse 10-12). Bielefeld: Welthaus Bielefeld.

Wilson, K. (2012) Race, Racism and Development: Interrogating history, discourse and practice. London: Zed Books.

WUS-Informationsstelle Bildungsauftrag Nord-Süd (2014) Ausgaben von Industriestaaten für Informations- und Bildungsarbeit im Bereich der Entwicklungszusammenarbeit. Wiesbaden: World University Service. Online. www.kooperation-international.de/uploads/media/OECD_ Flyer_2014_Ausgaben_2012.pdf (accessed 1 February 2018).

Ziai, A. (2007) Globale Strukturpolitik? Die Nord-Süd-Politik der BRD und das Dispositiv der Entwicklung im Zeitalter von neoliberaler Globalisierung und neuer Weltordnung. Münster: Westfälisches Dampfboot.

Ziai, A. (2011) 'The Millennium Development Goals: Back to the future?'. Third World Quarterly, 32 (1), 27-43

Ziai, A. (2013) ‘Das Imperium schlägt zurück: Georg Krämers Kritik am Antirassismus zeichnet ein verzerrtes Bild'. Welt-Sichten, 10. Online. www.welt-sichten.org/brennpunkte/18347/dasimperium-schlaegt-zurueck (accessed 1 October 2017). 